Review Article

Azzam Ahmed, Xianghui Wang*, and Ming Yang

\title{
Biocompatible materials of pulsatile and rotary blood pumps: A brief review
}

https://doi.org/10.1515/rams-2020-0009

Received Jul 08, 2019; accepted Jan 15, 2020

\begin{abstract}
The biomedical materials that have been used in the structure of heart pumps are classified as biocompatible, and these can be metals, polymers, ceramics, and composites. Their positions in the pump vary according to the part's function. Whereas various materials have different properties, all biomaterials chosen for cardiovascular applications should have excellent blood biocompatibility to reduce the likelihood of hemolysis and thrombosis. There are two major categories of the heart pumps; pulsatile and rotary blood pumps (axial and centrifugal) and the features of some of these materials allow them to be used in both. Rotary and pulsatile blood pump devices have to be fabricated from materials that do not result in adverse biological responses. The purpose of this review is to study the available biocompatible materials for the pulsatile and rotary blood pumps as clinically-approved materials and prototype heart pump materials. The current state of biocompatible materials of rotary and pulsatile blood pump construction is presented. Some recent applications of surface amendment technology on the materials for heart assist devices were also reviewed for better understanding. The limitations of heart assist devices, and the future direction of artificial heart elements have been considered. This review will be considered as a comprehensive reference to rapidly understanding the necessary research in the field of biocompatible materials of pulsatile and blood rotary pumps.
\end{abstract}

Keywords: Artificial hearts; biocompatible materials; blood biocompatibility; pulsatile pumps; rotary blood pumps

\footnotetext{
*Corresponding Author: Xianghui Wang: School of Physics and Material Science, East China Normal University, Shanghai 200241, China; Email: xhwang@phy.ecnu.edu.cn; Tel: 86-21-54342937

Azzam Ahmed, Ming Yang: Department of Instrument Science and Engineering, Shanghai Jiao Tong University, Shanghai 200240, China
}

¿ Open Access. (๑) 2020 A. Ahmed et al., published by De Gruyter.

(cc) BY 4.0 License

\section{Abbreviations}

\author{
C-TAH Carmat Total Artificial Heart \\ CFD Computational fluid dynamics \\ CRT Cardiac resynchronization treatment \\ DLC Diamond-Like Carbon \\ LVAD Left Ventricular Assist Device \\ MAGLEV Magnetic levitation \\ MPC Methacryloyloxyethyl Phosphorylcholine \\ PC Polycarbonate \\ PDMS Polydimethylsiloxane \\ PMMA Polymethylmethacrylate \\ PTFE Polytetrafluoroethylene \\ RBC Red Blood Cell \\ RVAD Right Ventricular Assist Device \\ TAH Total Artificial Heart \\ TiN Titanium Nitride \\ TM Thrombomodulin
}

UHMWPE Ultra-High-Molecular-Weight Polyethylene

UPVAD Undulation pump Ventricular Assist Device

VADs Ventricular Assist Devices

\section{Introduction}

The devices that have predominantly been developed to improve the pumping function of the heart in the event of a failure are Ventricular Assist Devices (VADs) (pulsatile and blood rotary pumps) and the Total Artificial Heart (TAH). Heart failure is a serious condition, and there is usually no cure. Transplantation is the right way for everyone having a weakened heart, or congestive heart failure to covering these cases. However, it is most frequently using a suitable heart pump in the left ventricle because of the most typical case of heart failure. VADs have become an increasingly useful option for patients with heart failure [1]. Basing on their properties, rotary blood pumps have proved to be stronger than pulsatile pumps; these use either an axial circulation pump or a centrifugal pump. Both types contain a core rotor comprising everlasting magnets. In typical centrifugal pumps, the rotors are shaped to boost the 
bloodstream circumferentially, whereas, in the axial circulation pumps, the rotors happen to be even more or not as much cylindrical and blades that are helical triggering blood acceleration in the rotor's axis direction.

The unique advantages of rotary flow pumps are more compact dimensions and weight, a smooth structure with a few moving parts, less chance of stasis and thromboembolic events, and reduced vitality consumption. The style, performance structures, materials structure of the artificial hearts should consider as important issues for improvements and products constantly [2]. Through the entire last two decades, advances development have already made in the manufacture of biocompatible and biodegradable materials for medical applications. In the biomedical discipline, the aim is to improve and characterize artificial materials or, basically, "spare parts" for work within our body to measure, restore and improve physical abilities and increase survival and quality of life.

\section{Pulsatile and rotary blood pumps biomaterials}

Biomaterials refer to substances of synthetic or natural origin which work extremely well for a designated period alone or as part of another object within the body. These are used to assist or replace tissues or organs in the body. In the selection of biomaterials for use in the design of any medical device, compatibility by the human body is considered the most important thing. In general, these factors determine the viability of any biomaterial for use in medical devices or implants (i) biomaterial's substance and biological performance, (ii) Implant's biocompatibility, and (iii) the health condition of the human body. Blood pumps might be made out of animal tissue, plastic, ceramic, and metal in the light of the required functional and mechanical properties [3]. There are various types of materials used in the biomedical field and these can be grouped into (a) metals (b) ceramics (c) polymers and (d) composite materials created from a diverse blend of (a), (b) and (c) [4-6]. Some long-lasting polyurethane and plastic pumps have also been developed $[7,8]$. The materials for making blood pumps can be classified into the coating and bearing materials. These are required to be fully biocompatible for healthy interaction with the human body, in addition to which they should possess good mechanical and thermal properties. There are specific requirements that an implant or device must meet for long-term use in the human body short of which the user is bound to experience dire side effects or even death [9]. As materials for artificial hearts, biocompatible plastic, and metal materials today are used [10]. Mac Murray et al. [11] fabricated a good blood pump with a biologically inspired external geometry (Figure 1) using poroelastic foam for the simple fabrication of superior soft robots. This pump offers an alternative to current VADs. Additionally, both primary material parts of the pump (PDMS and Kevlar) are biocompatible. The available tests for biocompatibility of the material are material/chemical characterization (ISO 10993-18), cytotoxicity, hemocompatibility, implantation testing, irritation, sensitization, and systemic toxicity - ISO Acute Systemic Toxicity, pyrogenicity and USP plastics (USP Class VI) [12]. Non-toxic is an important factor for materials used in surgical implants and medical devices [13]. Akshay et al. [14] fabricated an artificial heart from Platinum cured silicone rubber (ECOFLEX 0010). In this, a biocompatible coating was applied to the blood-contacting surfaces to limit the incidence of thrombus formation in the left ventricular assist devices [15]. A lot of research has been done to explore ways of controlling thrombus formation. In this regard, titanium and polycarbonate were used as anti-thrombogenic materials [16]. At NASA's Langley Research Center in Hampton, Va., a sophisticated biologically inert resin was created that is very much suitable for implantable medical devices [17]. For a biomaterial to be appropriate for use as an implant, it should possess some special properties to enable it to stay permanently within the body with less possibility of rejection [18]. The biocompatibility means the power of a material to execute with an appropriate host response in a specific application [19]. Carpentier et al. [20] have been used a bioprosthetic material for the total artificial heart (Figure 2) as the first clinical. The requirements of the devices must be biocompatible and not consuming excessive amounts of power [21].

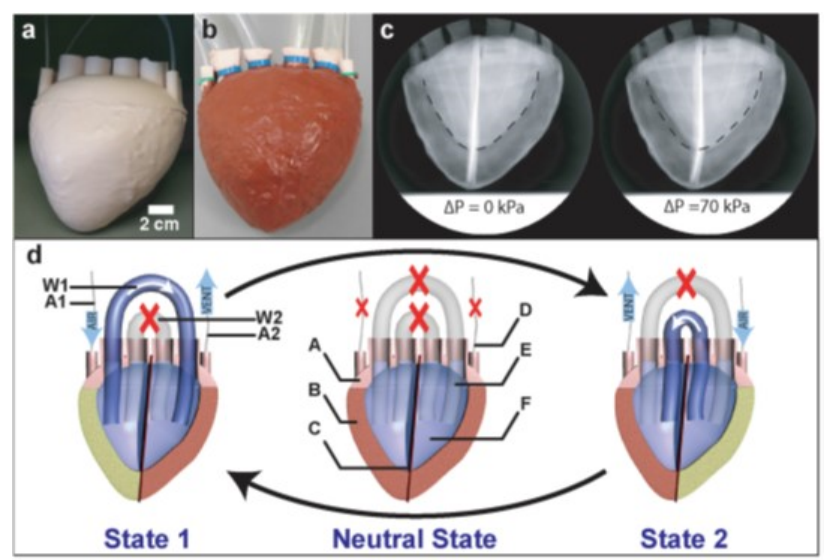

Figure 1: Fabricated a functional fluid pump with a biologically inspired external geometry. 


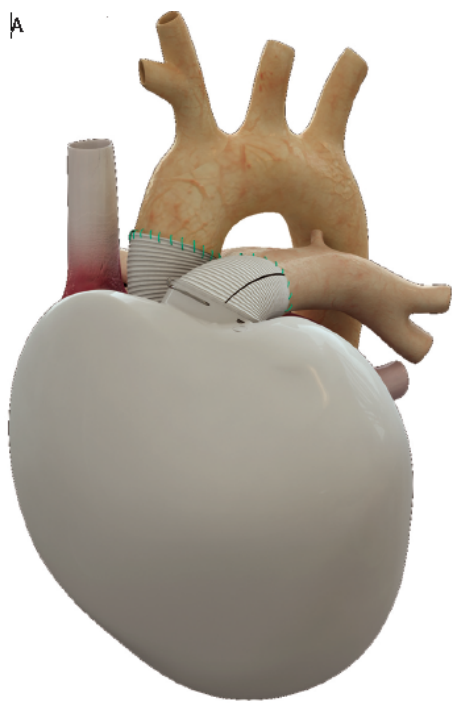

Figure 2: The CARMAT bioprosthetic total artificial heart.

Artificial hearts materials should be selected according to their hemocompatibility and structural properties. Other considerations made when selecting polymers or metals for use in implantable materials must be careful about strength, overall time and rate of degradation/corrosion (a very high degradation rate can associate with inflammations), biocompatibility and lack of toxicity. The features of an ultimate implantable heart pump are biocompatible, small, an absence of percutaneous lines, reliable, low-energy consumption, easy to implant and explant, allowing quick discharge and low cost. Due to lack of literature review on artificial hearts such as blood pulsatile and rotary pumps materials, here we present a comprehensive overview about the clinical and prototype blood rotary (axial and centrifugal flow pump) and pulsatile pumps regarding biocompatible materials, by looking at their advantages, disadvantages, properties and applications.

\section{The clinical implantable of heart pumps}

\subsection{Pulsatile blood pumps}

Whereas pulsatile pumps offer physiological pulsatility when used, these are not without shortcomings amongst which we have infections and mechanical failures due to the large size and advanced pump function. The confinements of the old pulsatile pumps are a great size, intrusiveness, and the requirement for extracorporeal support connections. Some of the most commonly used clinical im- plantable pulsatile heart pumps and their specifications are presented in Table 1 below.

Table 1: The clinical pulsatile implantable heart pumps.

\begin{tabular}{|c|c|c|c|}
\hline Device & Manufacturer & Materials & Ref. \\
\hline $\begin{array}{l}\text { HeartMate } \\
\text { I (XVE) }\end{array}$ & Thoratec & $\begin{array}{l}\text { Sintered titanium } \\
\text { Woven polyester } \\
\text { Textured materials }\end{array}$ & $\begin{array}{c}{[15,22,} \\
23]\end{array}$ \\
\hline IVAD/PVAD & Thoratec & $\begin{array}{c}\text { Polyurethane } \\
\text { Semi-rigid polyurethane } \\
\text { Titanium } \\
\text { Heparin }\end{array}$ & $\begin{array}{c}{[15,22,} \\
23]\end{array}$ \\
\hline EXCOR & Berlin Heart & $\begin{array}{l}\text { Polyurethane } \\
\text { Silicone } \\
\text { Graphite powder } \\
\text { Heparin }\end{array}$ & $\begin{array}{c}{[15,22-} \\
24]\end{array}$ \\
\hline$A B 5000$ & Abiomed & $\begin{array}{c}\text { Polyurethane } \\
\text { epoxy, aluminium } \\
\text { Polycarbonate } \\
\text { Titanium } \\
\text { Heparin }\end{array}$ & {$[15,23]$} \\
\hline Novacor & World Heart & Polyurethane & $\begin{array}{c}{[22,25,} \\
26]\end{array}$ \\
\hline
\end{tabular}

\subsection{Axial Blood Pump}

An axial flow pump is, in very basic terms, a propeller inside of a tube. It consists of a screw-type impeller that spins pushing fluid through the tube. Unlike a centrifugal pump, the fluid that passes through an axial flow pump does not change direction. The axial flow pump takes blood from 
the left ventricle through an inlet cannula. The blood spins through the pump chamber and is pushed out through an outlet cannula to the ascending aorta (the major blood vessel that supplies the body). As of late axial blood, pumps have been enhanced with a few features, for example, magnetic levitation (maglev); Computational fluid dynamics (CFD), improved impeller and diffuser blades, biocompatible materials, and percutaneous power transference. The clinical implantable axial heart pumps and their specifications such as the device, manufacturer and material names, are presented in Table 2.

Table 2: The clinical implantable of axial heart pumps.

\begin{tabular}{|c|c|c|c|}
\hline Device & Manufacturer & Materials & Ref. \\
\hline $\begin{array}{l}\text { HeartMate } \\
\text { II }\end{array}$ & Thoratec & $\begin{array}{l}\text { Polished titanium } \\
\text { Textured titanium } \\
\text { microsphere } \\
\text { Textured material } \\
\text { Ceramic-aluminium } \\
\text { oxide }\end{array}$ & $\begin{array}{c}{[15,22,} \\
27]\end{array}$ \\
\hline $\begin{array}{l}\text { Jarvik } 2000 \\
\text { FlowMaker }\end{array}$ & Jarvik Heart & $\begin{array}{l}\text { Ceramic for bearings } \\
\text { Titanium } \\
\text { Polyester for the } \\
\text { sewing ring }\end{array}$ & $\begin{array}{c}{[15,22,} \\
27]\end{array}$ \\
\hline $\begin{array}{l}\text { Heart } \\
\text { Assist } 5\end{array}$ & $\begin{array}{l}\text { MicroMed } \\
\text { Cardiovascu- }\end{array}$ & $\begin{array}{l}\text { Titanium } \\
\text { Cameda }{ }^{\circledR}\end{array}$ & {$[15,27]$} \\
\hline $\begin{array}{l}\text { Adult VAD } \\
\text { InCOR }\end{array}$ & $\begin{array}{c}\text { lar } \\
\text { Berlin Heart }\end{array}$ & $\begin{array}{c}\text { biocompatible coating } \\
\text { Heparin-coated with } \\
\text { Carmeda }{ }^{\circledR}\end{array}$ & $\begin{array}{c}{[15,22,} \\
27]\end{array}$ \\
\hline $\begin{array}{l}\text { HeartMate } \\
\text { III }\end{array}$ & Thoratec & $\begin{array}{l}\text { Polished titanium } \\
\text { Textured titanium } \\
\text { microsphere }\end{array}$ & $\begin{array}{c}{[15,22,} \\
28]\end{array}$ \\
\hline $\begin{array}{l}\text { MicroMed } \\
\text { DeBakey } \\
\text { VAD }\end{array}$ & MicroMed & $\begin{array}{c}\text { Titanium } \\
\text { Heparin } \\
\text { Dacron fabric } \\
\text { Silicone } \\
\text { Polyester }\end{array}$ & $\begin{array}{c}{[15,22,} \\
27]\end{array}$ \\
\hline Synergy & $\begin{array}{l}\text { CircuLite, } \\
\text { Saddle } \\
\text { Brook, NJ }\end{array}$ & $\begin{array}{l}\text { Titanium } \\
\text { Silicone } \\
\text { PTFE }\end{array}$ & {$[22,27]$} \\
\hline
\end{tabular}

\subsection{Centrifugal Blood Pump}

Centrifugal pumps have relatively smooth, disk-designed impellers with radial fins on the fluid side of the disk. Blood is drawn into the pump close to the focal point of the impeller and is divergently flung radially outwards by the turning activities of the impeller. The veins collect in a spiral pit where it is driven out from the draw unrelated to the outside width of the impeller. Centrifugal pumps can achieve physiological flow costs (5 liters/minute) and pres- sures (100 mmHg) at impeller speeds of 2000 to $4000 \mathrm{rev}$ olutions each minute (RPM). A centrifugal blood pump is smaller than a pulsatile blood pump. However, the smaller implantable blood pumps are more desirable as they offer a higher quality of life for heart disease patients [29]. An impeller is a very critical part of centrifugal blood pumps [30]. The clinical implantable centrifugal heart pumps and their specifications such as device, manufacturer and material name, are presented in Table 3. The drive modes of the axial and centrifugal flow pumps are shown in Figure 3.

Table 3: The clinical implantable of centrifugal heart pumps.

\begin{tabular}{|c|c|c|c|}
\hline Device & Manufacturer & Materials & Ref. \\
\hline WorldHeart & Levacor & Polished titanium & $\begin{array}{c}{[15,22,} \\
27]\end{array}$ \\
\hline DuraHeart & Terumo & $\begin{array}{c}\text { Titanium } \\
\text { Stainless steel } \\
\text { Heparin coating }\end{array}$ & $\begin{array}{c}{[15,22,} \\
27]\end{array}$ \\
\hline HVAD & HeartWare & $\begin{array}{c}\text { Ceramic } \\
\text { Titanium } \\
\text { woven polyester fabric } \\
\text { Polyether Ether Ketone }\end{array}$ & $\begin{array}{c}{[15,22,} \\
27]\end{array}$ \\
\hline VentrAssist & Ventracor & $\begin{array}{c}\text { Titanium } \\
\text { Silicone } \\
\text { Diamond-like carbon }\end{array}$ & $\begin{array}{c}{[15,22,} \\
31]\end{array}$ \\
\hline $\begin{array}{l}\text { MTIHeartLVAD } \\
\text { MVAD }\end{array}$ & $\begin{array}{l}\text { Mitiheart } \\
\text { HeartWare }\end{array}$ & $\begin{array}{l}\text { Polycarbonate } \\
1 \longrightarrow \text { Ceramic } \\
2 \longrightarrow \text { Titanium } \\
3 \longrightarrow \text { woven polyester } \\
\text { fabric }\end{array}$ & $\begin{array}{c}{[32]} \\
{[22,33,} \\
34]\end{array}$ \\
\hline $\begin{array}{l}\text { Levitronix } \\
\text { CentriMag }\end{array}$ & Levitronix & $\begin{array}{c}\text { Polycarbonate } \\
\text { Woven polyester } \\
\text { Heparin }\end{array}$ & [35] \\
\hline $\begin{array}{l}\text { EVAHEART } \\
\text { LVAS }\end{array}$ & $\begin{array}{l}\text { EVAHEART } \\
\text { USA, } \\
\text { Pittsburgh, } \\
\text { PA }\end{array}$ & $\begin{array}{c}\text { Titanium } \\
\text { Diamond-like carbon }\end{array}$ & [36] \\
\hline
\end{tabular}

\section{Design and materials of blood pumps}

There are a few fundamental issues considered when developing blood pumps. The material used should enable blood to be pumped smoothly through the blood vessels and ensure that no coagulation takes place. Selected materials must be biocompatible, or the pump would not be feasible. The efficiency of the pump motor has to be enhanced so that insignificant heat is produced. Also, due to possible rejection, the aggregate volume and surface area 


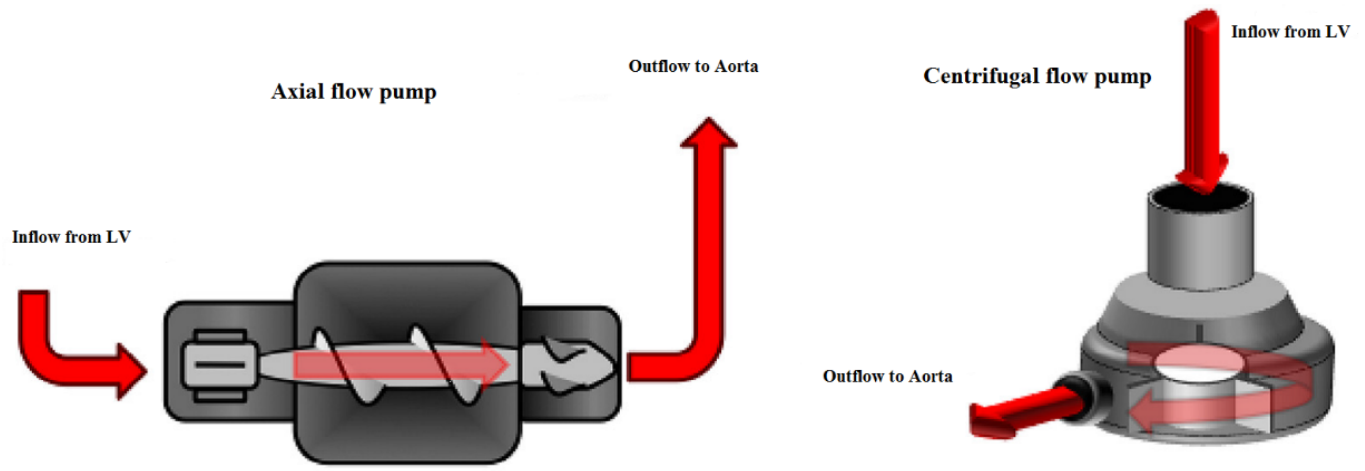

Figure 3: Axial and centrifugal flow pump [37].

of the whole device must be kept as small as possible. The required performances for the blood pumps are mean pressure rise of 100 and $20 \mathrm{mmHg}$ for LVAD and RVAD respectively and mean blood rate of $5 \mathrm{~L} / \mathrm{min}$ for the full support of an adult at rest $[43,44]$. Various parameters are considered during the design of a centrifugal impeller. These include; pump size, number of blades, blade thickness, inlet and outlet width, inlet and outlet diameters and angles [45]. Generally, blood pumps are fabricated from steel, plastic and ceramic. A titanium-aluminum-vanadium composite has been utilized for the pump and extra metal parts since it is usually biocompatible and has reasonable auxiliary houses. Titanium alloys are the metal materials used as a part of blood pumps and tissue-contacting surfaces for they are biocompatible and have consistent mechanical properties. For blood interfacing surfaces, titanium is machined to a particular level of wrap up. The appearances in contact with blood may get a special coating of titanium microspheres that permanently bond to the surface. With this layer, blood cells adhere to the surface [46-61].

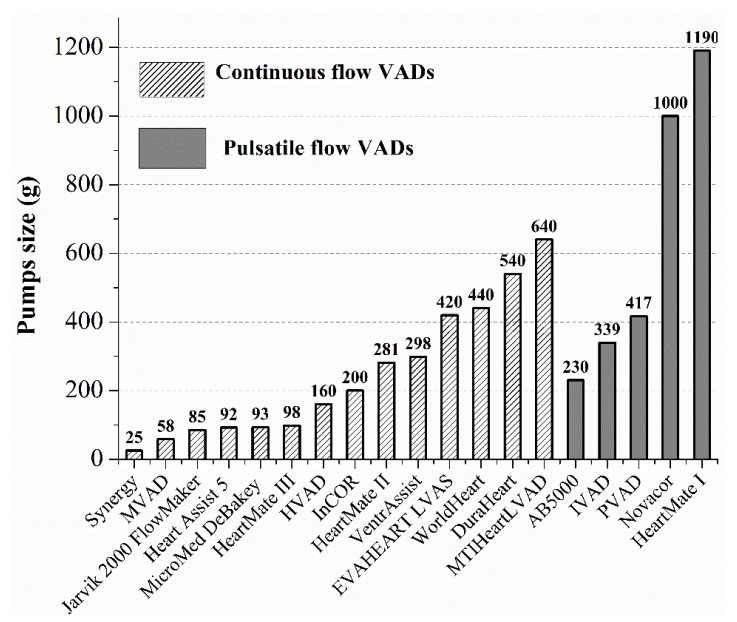

Figure 4: Pump size comparison of VADs.
A particular type of polyurethane polymer has been used as a surface coating to provide blood cell adherence [46, 48,57 ] whereas polyester is often employed in other parts of the system such as tubular grafts [57, 62, 63]. Different materials, for example, ceramic (silicon nitride, zirconia, and alumina) and polymers such as ultrahigh molecular weight polyethylene, polyetheretherketone, and polyoxymethylene, have been assessed for such systems to avert wear and thrombosis $[64,65]$. To ensure biocompatibility, the bio-derived materials, as well as extracellular matrix (ECM) derived materials are preferred [66]. A very soft robotic device was created with materials properties equivalent to those of indigenous heart cells that sit snugly around the center and ventricular assistance without ever before contacting bloodstream. The authors articulate that the artificial muscles could possibly be selectively activated to twist, compress, or simultaneously perform both actions on one area or both sides of the heart [67]. To determine the influence of material densities on the total weight of the pumps, a pump size comparison of VADs is shown in Figure 4. It can be noted that the recent VADs weight is less than $100 \mathrm{~g}$ this is in comparison to the earlier VADs whose weight was more than $1000 \mathrm{~g}$.

\subsection{Pulsatile blood pumps materials}

In the pulsatile pumps, the flow is driven either pneumatically or by a pusher plate against a segmented polyurethane blood sac for the LionHeart ${ }^{\mathrm{TM}}$ Left Ventricular Assist System [68]. The inert materials of Harvard Apparatus Pulsatile Blood Pumps are silicone rubber, acrylic plastic, and PTFE contacting the fluid [69, 70]. Lee et al. [71] have designed a new pulsatile pump, which is characterized by minimal-occlusion of blood-containing tubing, no requirement for valves, and no blood flow regurgitation. 
The materials of the pump are an aluminum alloy for the body and silicone for the inlet and outlet [71]. A prototype model of the optimized blood pump was made using a three-axis computer machine tool by carving pieces of non-foamed polyurethane, and the pumps were fabricated using ceramic, polyurethane and PTFE (Teflon) for the ball bearing [72]. Fukunaga et al. [73] have also used a linear drive actuator for a pulsatile blood pump. The materials used were polyurethane for the blood pump housing and the pusher plate, Japanese medical-grade segmented polyurethane for the diaphragm, solvent dimethylformamide to bond the membrane to the pusher plate and an aluminum alloy for the actuator housing [73]. Similarly, Förster et al. designed a small pulsatile blood pump (polymeric pump) using polyurethane for the inlet and outlet positions and polyurethane sheets for the pump chamber and the membranes [74]. Whereas Abe et al. reduced the size of the implantable pulsatile ventricular assist device (VAD) using an undulation pump (UPVAD) using polyurethane-coated titanium [75]. The low-cost pulsatile blood pumps, two types of polymer bileaflet valves with different configurations for the valve seats were developed by Iwasaki et al. [76]. The materials used for the ReinHeart TAH pulsatile blood pump were methylmethacrylate-acrylonitrile-butadiene-styrene for the ReinHeart actuator, a polyurethane membrane separating the drive unit from the blood flow inside the ventricles, mechanical bileaflet valves used for the inlet and outlet as well as polyurethane for the blood sac [77].

\subsection{Centrifugal and Axial Blood Pump materials}

The impeller of the centrifugal and axial blood pump is usually made of ceramics, titanium, and other metals [78-80]. The impeller of the flow and housing pumps can be fabricated from epoxy and urethane resins, respectively. Materials used in prototype VADs such as in the impeller sometimes cannot coat but polish to give a smooth surface. In one of the procedures, the inner surface of the pump housing was coated with segmented polyurethane (K-III, Macrotec, Sapporo, Japan), and the impeller sprayed with a black coating except for the top (shroud) surfaces of blades. The volute housing was made of transparent material (polymethylmethacrylate, PMMA) [81]. The shaft and bearing were made of titanium or stainless steel, and the hemolytic properties varied depending on the design of the bearing [82]. The stator was molded with epoxy resin to prevent water infiltration [83]. In vivo, the surface of the shaft and bearing were coated with 2 methacryloyloxyethyl phosphorylcholine (MPC) polymer, and it was sufficient to avoid thrombus formation. A careful treatment of the anti-thrombogenic material coating was necessary [84]. Sometimes Polytetrafluoroethylene (Teflon) polymer in the form of a sheet is placed between the impeller and the casing on the motor side to decrease friction as well as, impeller wall made of the transparent acrylic [29]. The pump materials in contact with the blood are primarily Polycarbonate (PC), and the pivot bearing is a combination of stainless steel (SUS) ball and a receptacle of ultra-high-molecular-weight polyethylene (UHMWPE) [85]. The benefit of rotary heart pumps is the revolutionization of advanced heart failure care [28]. Table 4 gives a summary of biocompatible materials (Metals and Polymers) and their specifications.

The properties and specific application areas for the most common biocompatible polymer materials employed in artificial hearts are presented in Table 5. Also, the thermal properties of the conventional polymers used in artificial hearts are given in Table 6.

\section{Coating materials of the blood pumps}

The objectives of the coating materials of the blood pumps are to amend the surfaces contacting blood to improve the blood compatibility (hemocompatibility). Conventional coating materials have been utilized for the blood-contacting covers and surface coatings of the ventricular assist devices, as shown in Table 7.

Titanium nitride coatings have not been utilized for commercial VADs on account of their low performance concerning wear resistance. Given that 2methacryloyloxyethyl phosphorylcholine (MPC) polymer is biodegradable, this constrains its lifetime. Nano-and microfabrication methods are relied upon to assume an important role in the creation of the textured or designed surfaces. It has been shown that such polymer surfaces could inhibit platelet adhesion and minimize protein adsorption significantly, resulting in their widespread usage in cardiovascular devices like dialysis, heart pumps, or VADs [100]. 


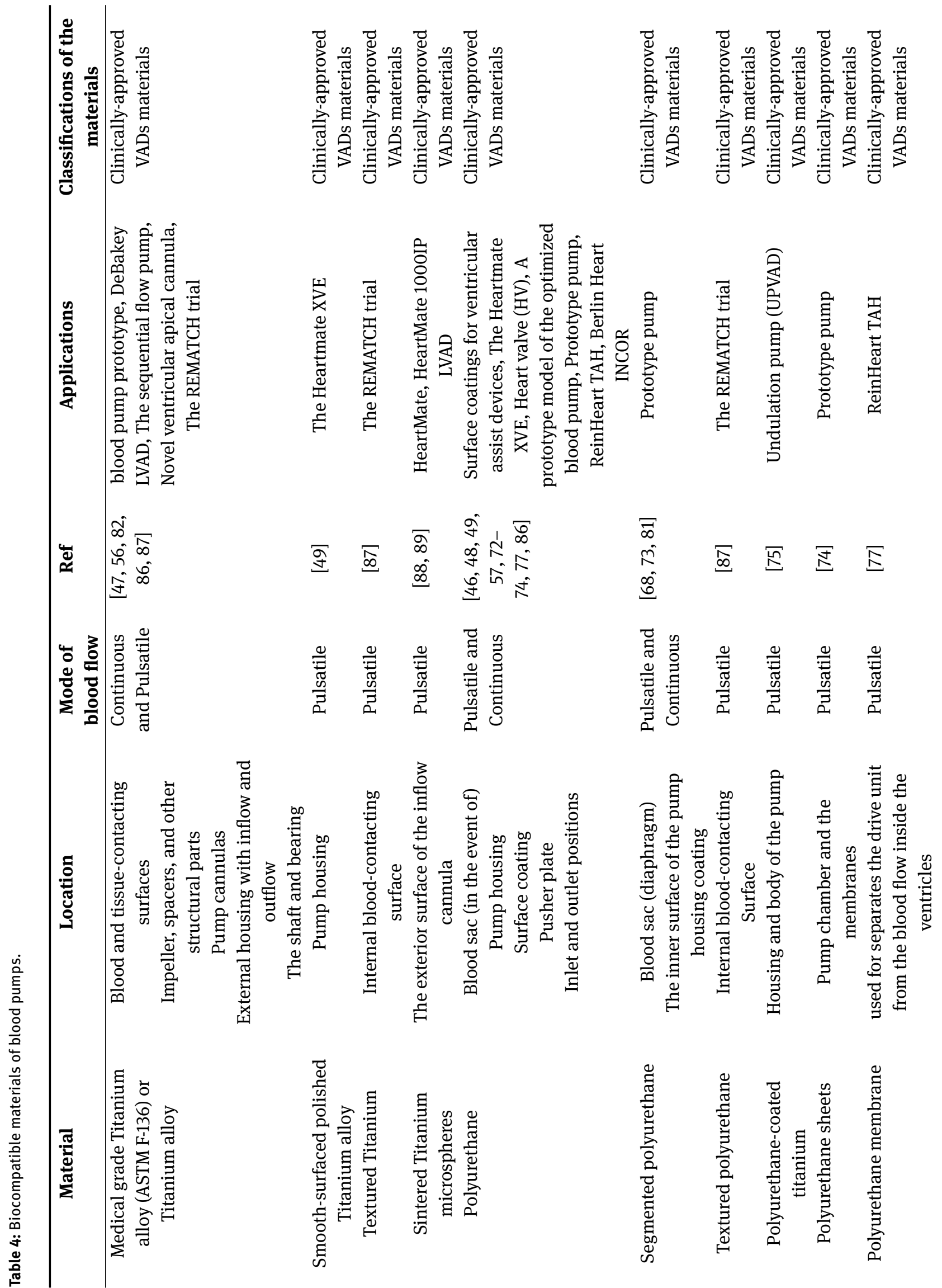



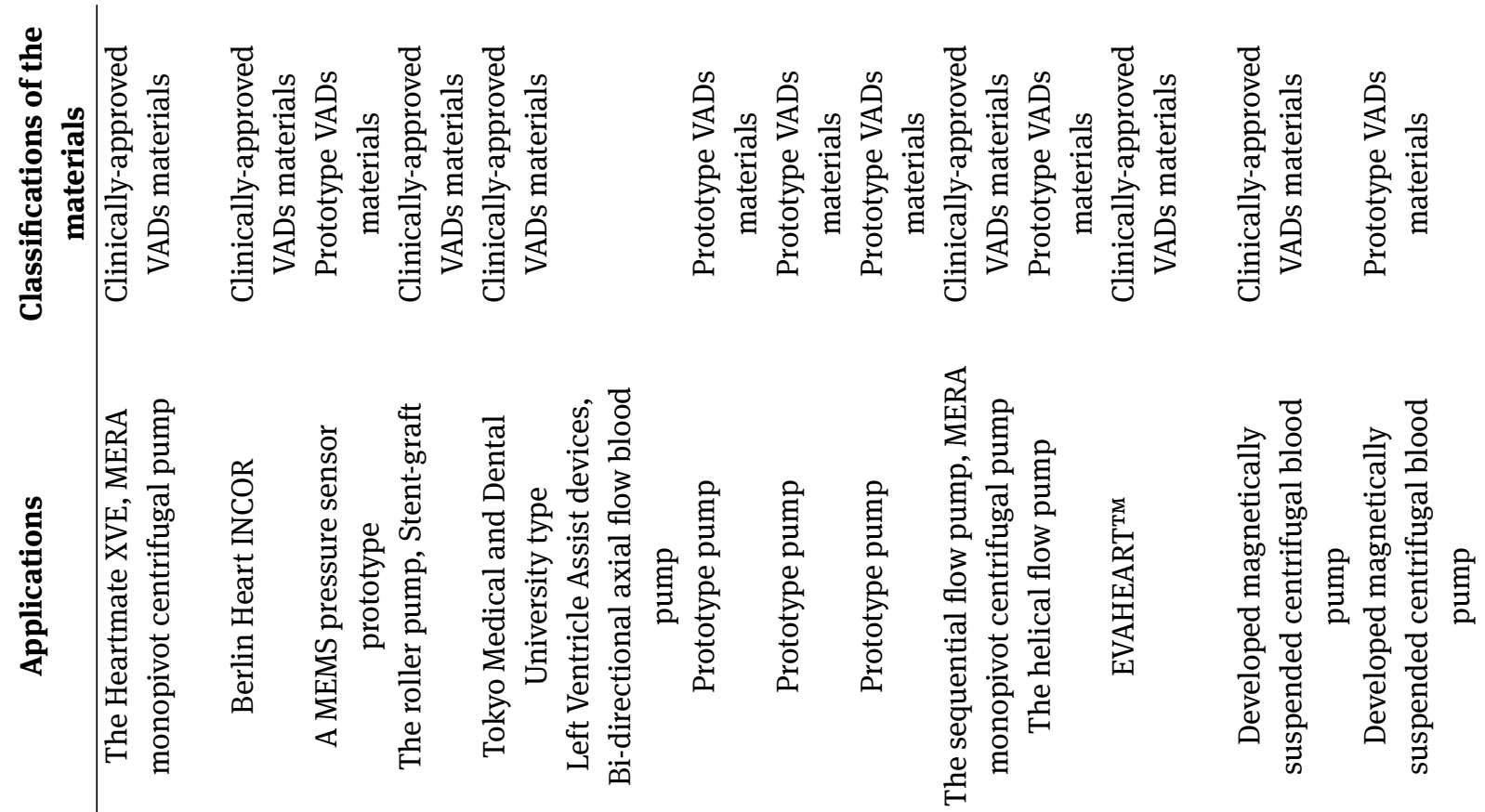

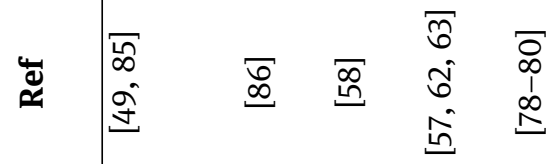

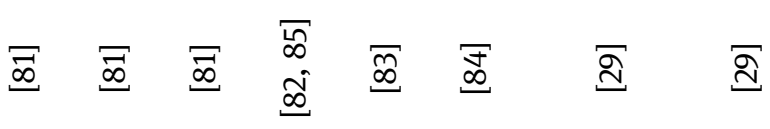
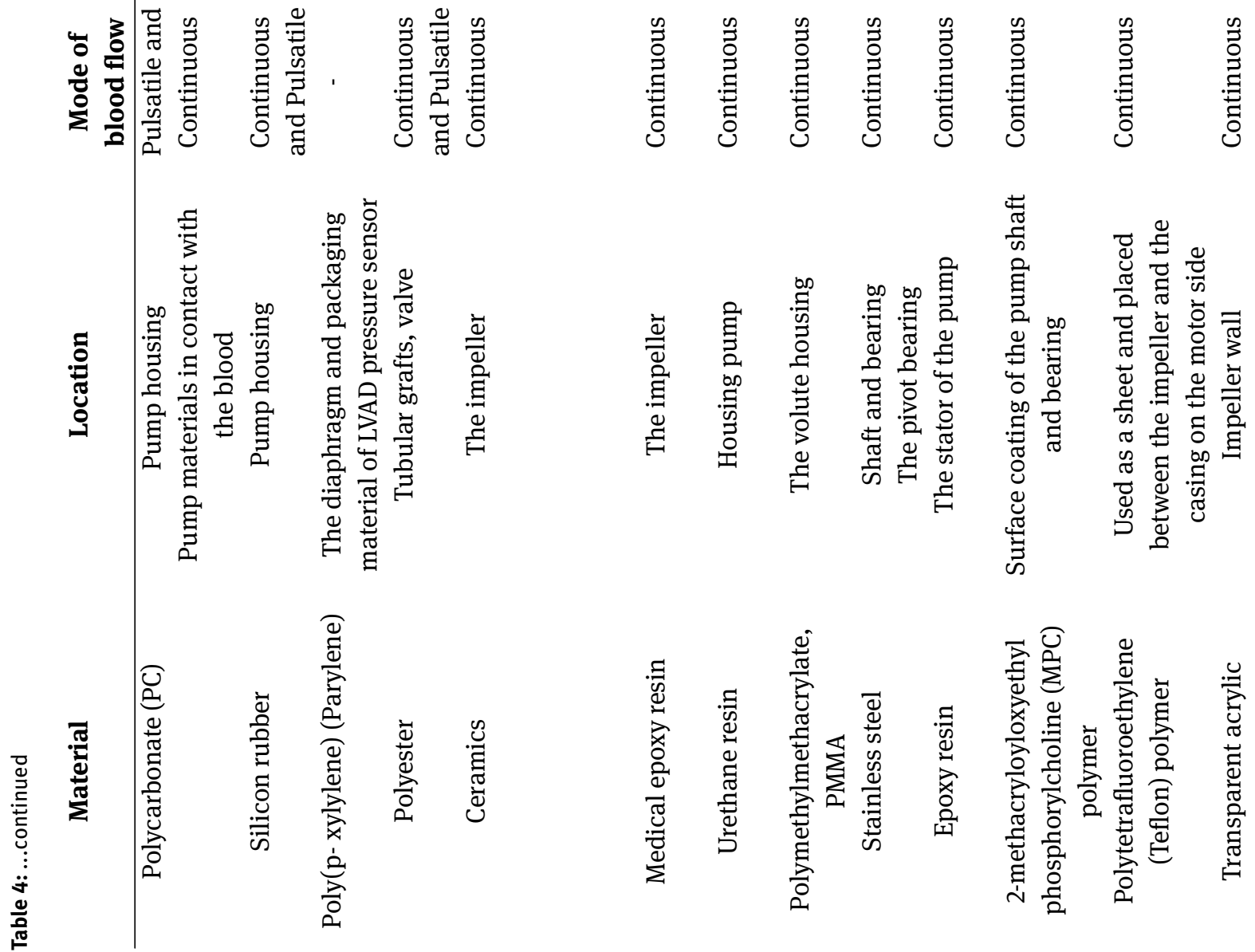


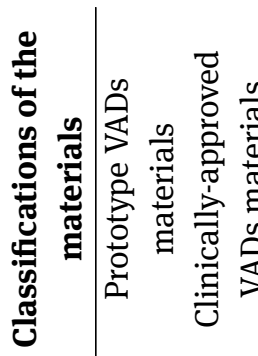

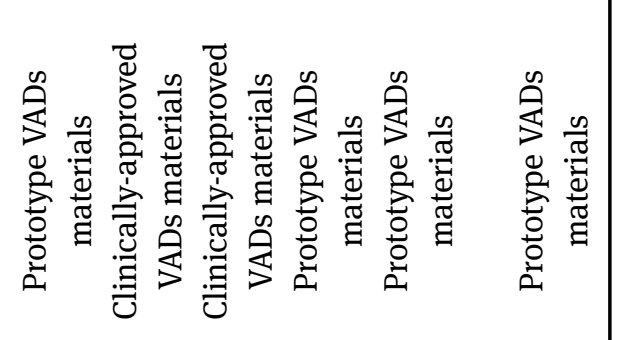

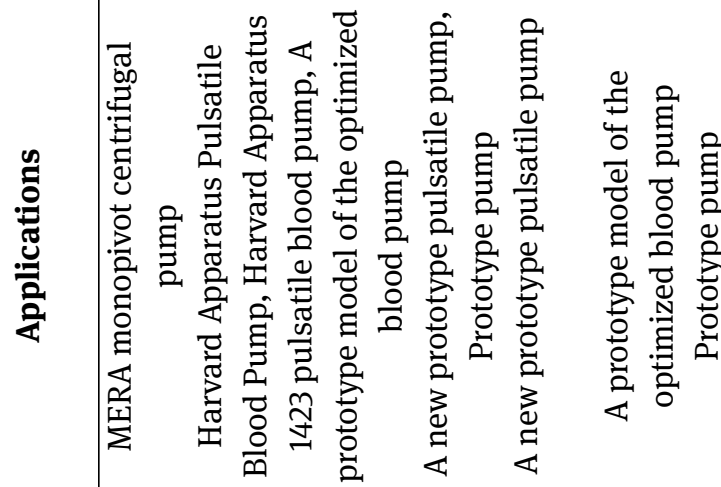

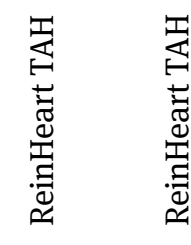

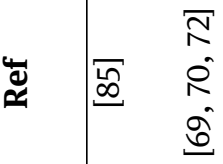

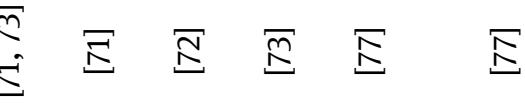

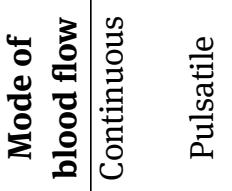

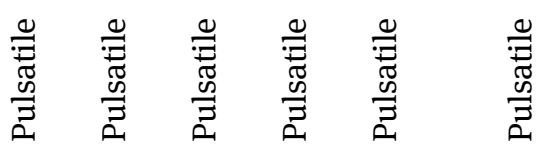

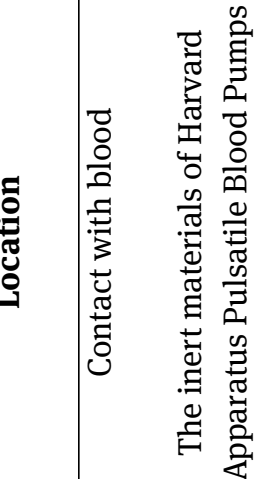

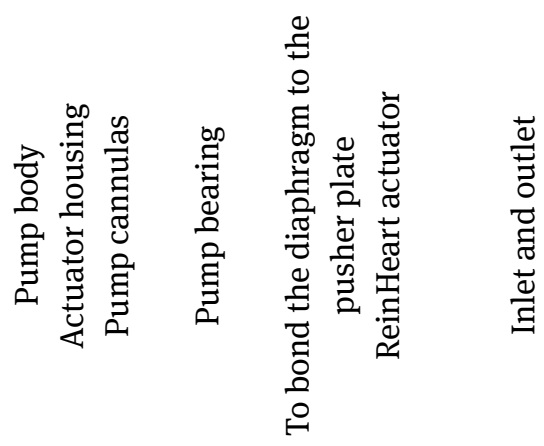
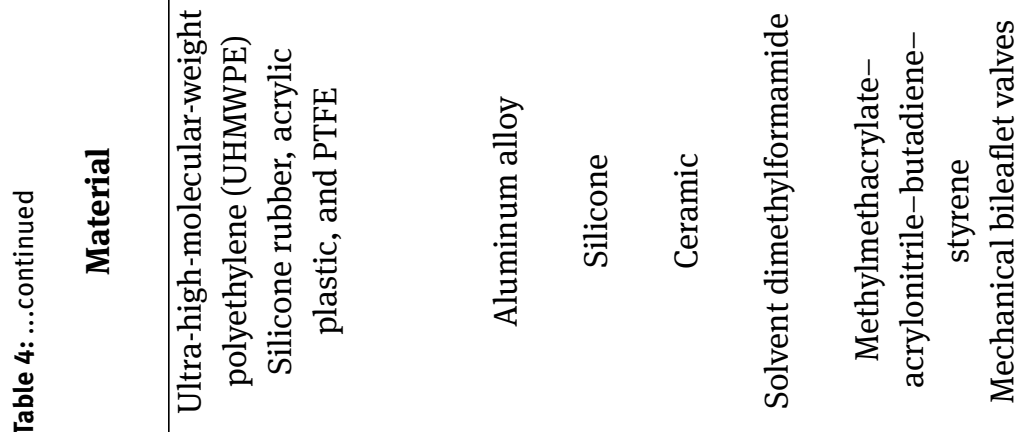


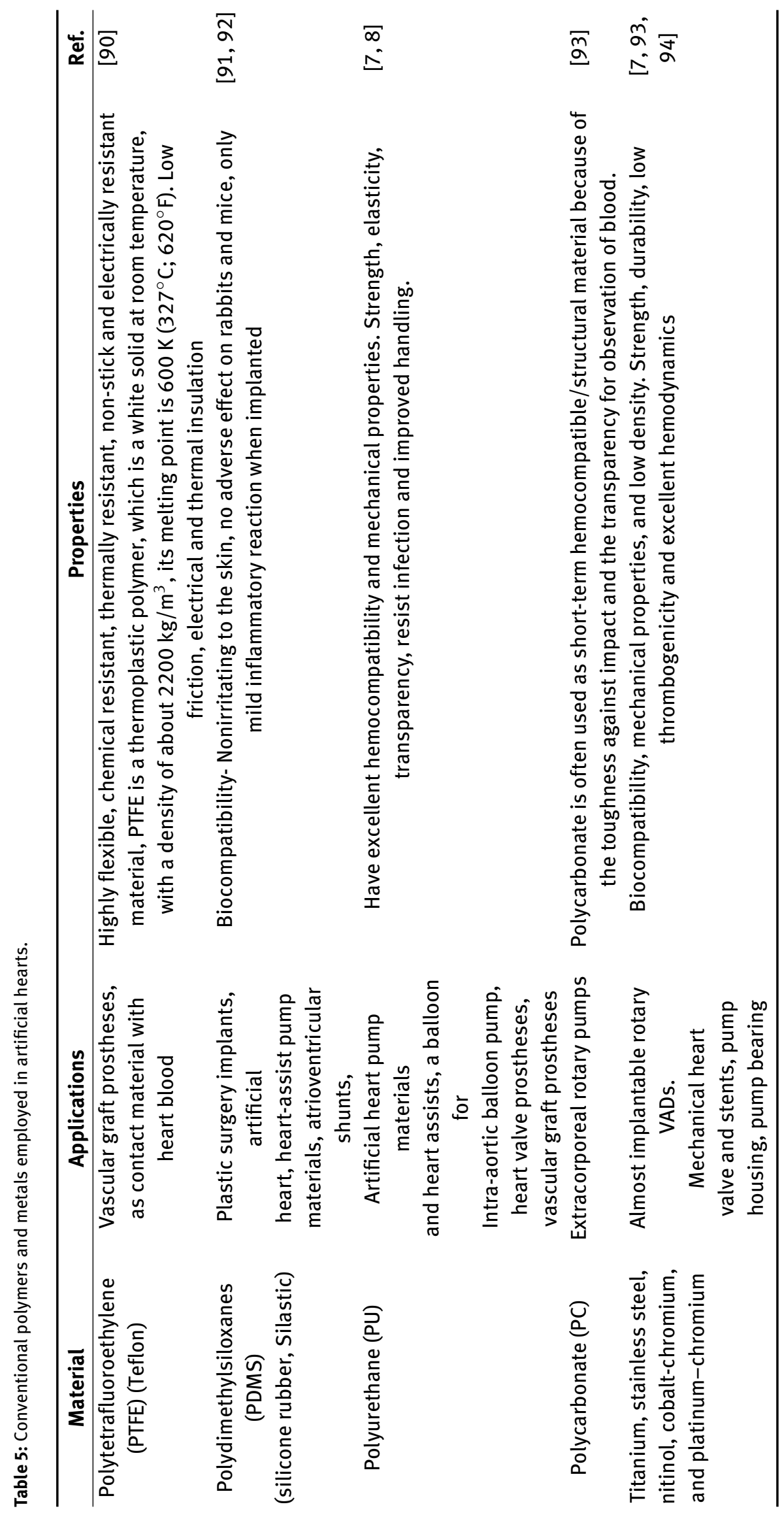


Table 6: Comparison of thermal properties of typical polymers used in artificial hearts $[92,95]$.

\begin{tabular}{|c|c|c|c|c|c|}
\hline Material & $\begin{array}{c}\text { Glass } \\
\text { temperature } \\
\left({ }^{\circ} \mathrm{C}\right)\end{array}$ & $\begin{array}{c}\text { Melting } \\
\text { temperature } \\
\left({ }^{\circ} \mathrm{C}\right)\end{array}$ & $\begin{array}{l}\text { Thermal } \\
\text { Conductivity } \\
(\mathrm{W} /(\mathrm{m} / \mathrm{K}))\end{array}$ & $\begin{array}{l}\text { Specific heat } \\
(\mathrm{J} / \mathrm{kg} \mathrm{K})\end{array}$ & $\begin{array}{c}\text { Thermal } \\
\text { expansion } \\
\left(\mathrm{X} 10^{-6} / \mathrm{K}\right)\end{array}$ \\
\hline Polycarbonate (PC) & 145 & - & $0.19-0.22$ & 1200 & $66-70$ \\
\hline PTFE (Teflon) & 127 & 327 & $0.23-0.25$ & 1000 & 100 \\
\hline Polyurethane (PU) & - & - & - & 1700 & 130 \\
\hline $\begin{array}{l}\text { Polydimethylsiloxanes } \\
\text { (PDMS) }\end{array}$ & 150 & $226-232$ & 0.15 & 1460 & 907 \\
\hline HDPE & -110 & $108-134$ & 0.46 & $1800-2700$ & $110-130$ \\
\hline LDPE & -110 & $125-136$ & $0.3-0.34$ & $1800-3400$ & $150-200$ \\
\hline PA11 & 46 & 190 & 0.28 & 2400 & $110-120$ \\
\hline PA12 & - & 190 & $0.22-0.24$ & $1.17-1.2$ & $80-100$ \\
\hline PA46 & 85 & 295 & 0.3 & 2100 & 75 \\
\hline PA66 & 78 & 260 & $0.25-0.27$ & 1670 & $70-100$ \\
\hline PA cast & $50-75$ & $215-220$ & 0.3 & - & $70-100$ \\
\hline
\end{tabular}

Table 7: Surface coating materials of the blood pump devices.

\begin{tabular}{cccc}
\hline NO & Material & Application & Ref. \\
\hline 1 & Heparin & DuraHeart pump & {$[85,96-$} \\
& & & $99]$ \\
2 & 2-methacryloyloxyethyl & EVAHEART pump & {$[36,48$,} \\
& phosphorylcholine (MPC) polymer & & $100-102]$ \\
3 & Avcothane & coated with segmented polyurethane for pulsatile VADs & {$[103-$} \\
& & & $105]$ \\
4 & Diamond-like carbon (DLC) & VADs & {$[36,106]$} \\
5 & Titanium nitride coating (TiN) & VADs & {$[48]$} \\
6 & Textured surfaces & VADs & {$[48]$} \\
7 & Endothelial cell(EC) linings & VADs & {$[48]$} \\
8 & BioMedFlex (BMF) thin-film coating & LVAD, RVAD and bearing materials & {$[51]$} \\
\hline
\end{tabular}

\section{Hemolysis and thrombosis of the blood pumps}

Hemolysis is the loss of hemoglobin and the destruction of red blood cells caused by high shear stress [107]. As the pump speeds improve, the speed gradient in the liquid increases, thus increasing the shear stress and hemolysis. Hemolysis occurs when a particular red blood cell (RBC) comes in contact with the material or its degradation products formed due to the shear tension generated as a result of relative movement between blood and the material surface. When compared to centrifugal blood pumps, hemolysis and blood cell devastation is commonly worse with axial blood pumps due to higher speeds in the latter. On the other hand, pulsatile pumping systems experience worse hemolysis compared to continuous flow pumps because of the existence of valves within the blood flow [108]. Another problem associated with artificial blood pumps is thrombosis. Thrombosis is the formation of a clot of blood cells, which may be activated by flow stagnation and abnormalities in the blood flow pattern, or walls of the blood vessel. Thrombosis-related incidents are one of the primary problems associated with axial blood pumps. To reduce hemolysis and thrombosis of the blood pumps, biological heart valves must be mechanically durable and chemically steady for long periods of time [109-111]. Adsorption of proteins onto the surface of the implanted heart biomaterial through the natural path or from the release regarding tissue factor from typically the damaged cells on the site of injury (extrinsic pathway) is the trigger for thrombosis [112]. The ability to harm a system through chemical substances is called toxicity. In higher organisms, toxicity might produce local and systemic effects. For localized toxicity, the 
adverse effects show up only in the impacted areas, whereas in associated toxicity, in addition to the local effects, the consequences traverse far away from the range of the implant's application area. Toxicity can be in the form of cytotoxicity, genotoxicity, mutagenicity, and carcinogenicity. Where cytotoxicity refers to the damage occurring within the individual cells, genotoxicity relates to the alteration of the base pair sequence of the genomic DNA and if genotoxicity is carried to the next generation through genes, then it leads to mutagenicity. The alterations in the base pair sometimes lead to the production of malignant tumors, and a condition referred to as carcinogenicity [113]. Immobilization of other anticoagulant molecules like thrombomodulin (TM) has shown improved results. Coimmobilization of TM along with urokinase and endothelial protein $\mathrm{C}$ receptor, has been investigated [114]. Utilization of TM as an immobilizing material resulted in the modulation of blood vessel tone, inhibition of platelet activation, and leukocyte adhesion. SiC coating for the heart pumps led to a decrease in platelet adhesion and reduced inflammatory reactions [115].

\section{Recent work of the blood pumps}

Roche et al. [67] created implantable devices or soft robots (Figure 5) that could mimic or assist in complex biological functions such as in the contraction of the heart muscle. The results of this study revealed that the implantable soft robot mimicked the form and function of the natural heart, with a stiffness value of the same order of magnitude as that of the heart tissue. A NASA-created material has been utilized as a part of Medtronic's Attain Ability left-heart lead cardiovascular CRT (Cardiac resynchronization treatment) support. It insulates the lead, which is an extraordinary wire that conveys energy from a CRT to the heart muscle. Electrical driving forces created by CRTs resynchronize heartbeats and enhance blood flow [17]. These materials were developed by NASA researchers recently, and they discovered that the biologically inert material was suitable for medical use, even in implantable devices. As a new method for the fabrication of ventricular assist devices using 3D printing techniques for inspection, the heart pumps in some specific congenital disabilities were studied by Farooqi et al. [116]. Berra et al. [117] also developed two different 3D pulsatile prototypes of the left ventricular assist devices using Poly Lactic Acid (PLA) and polyurethane as the pump materials. The results showed that flow in the prototype pump with two polyurethane membranes was better than in that with one [117]. Likewise, Borovjagin et al. [118] fabricated 3D cardiovascular tissues that were considered as great new patterns for a more cost-effective and timely translation of cardiovascular tissue equivalents. Several new studies have established the significance of new techniques, such as 3D printing, bioinspired approaches, and appropriate bionic materials to the fabrication of artificial hearts [66, 119-121].

\section{Limitations of heart assist devices}

For a successful surgery, implantation of the left ventricular assist devices (LVADs) in the human body needs a lot of caution. Whereas the research on the fabrication of the VADs has long-time support is still not well studied and needs to improve the pump design, biocompatible pump materials, materials biocompatibility, and performance. The most frequent early problems remain perioperative bleeding and right ventricular failure. The past is often the consequence of a continued heart operation and is usually related to perioperative coagulopathy and platelet malfunction stimulated by the extracorporeal flow. Also, swelling can be heightened by daily habit usage of anticoagulant and antiplatelet drugs in these patients afflicted by heart failure associated with consistent hepatic dysfunction extra to right heart failure [122]. The third generation of pumps allows suspension of a moving factor without any mechanical contact, thus eliminating heat generation and wear that will take place at the contact surface according to the type of the materials [123]. All the device runs in a biological environment at a body temp of $37^{\circ} \mathrm{C}$ and excessive humidity; these conditions can affect electrical efficiency and finalizing of human body substances joining the package and can cause a rise in the probability of failure. Thrombo-embolic confusions frequently imperil the patient with an embedded artificial valve. These intricacies are due to an intricate collaboration between blood, the material of the valve, and the flow. Unfortunately, it is still tough to rank or classify materials concerning their appropriateness for particular blood-contacting applications [109].

\section{The future direction of artificial hearts materials}

Reduction of the pumps and surgical devices and improvement in overall performance (design, structures, mechan- 
A
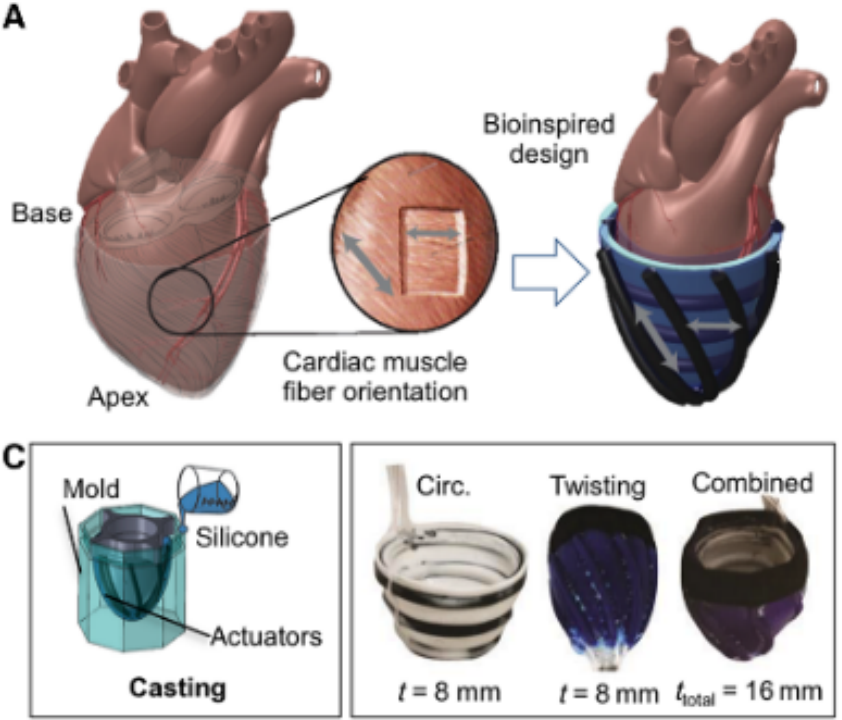

B

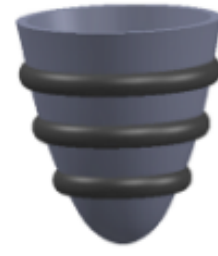

Compress decompress

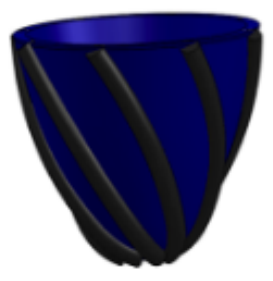

Twist Untwist

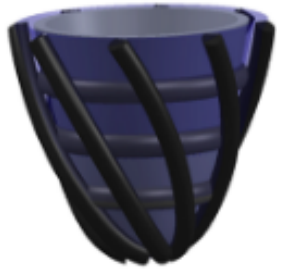

Compress,

decompress

Twist, untwist
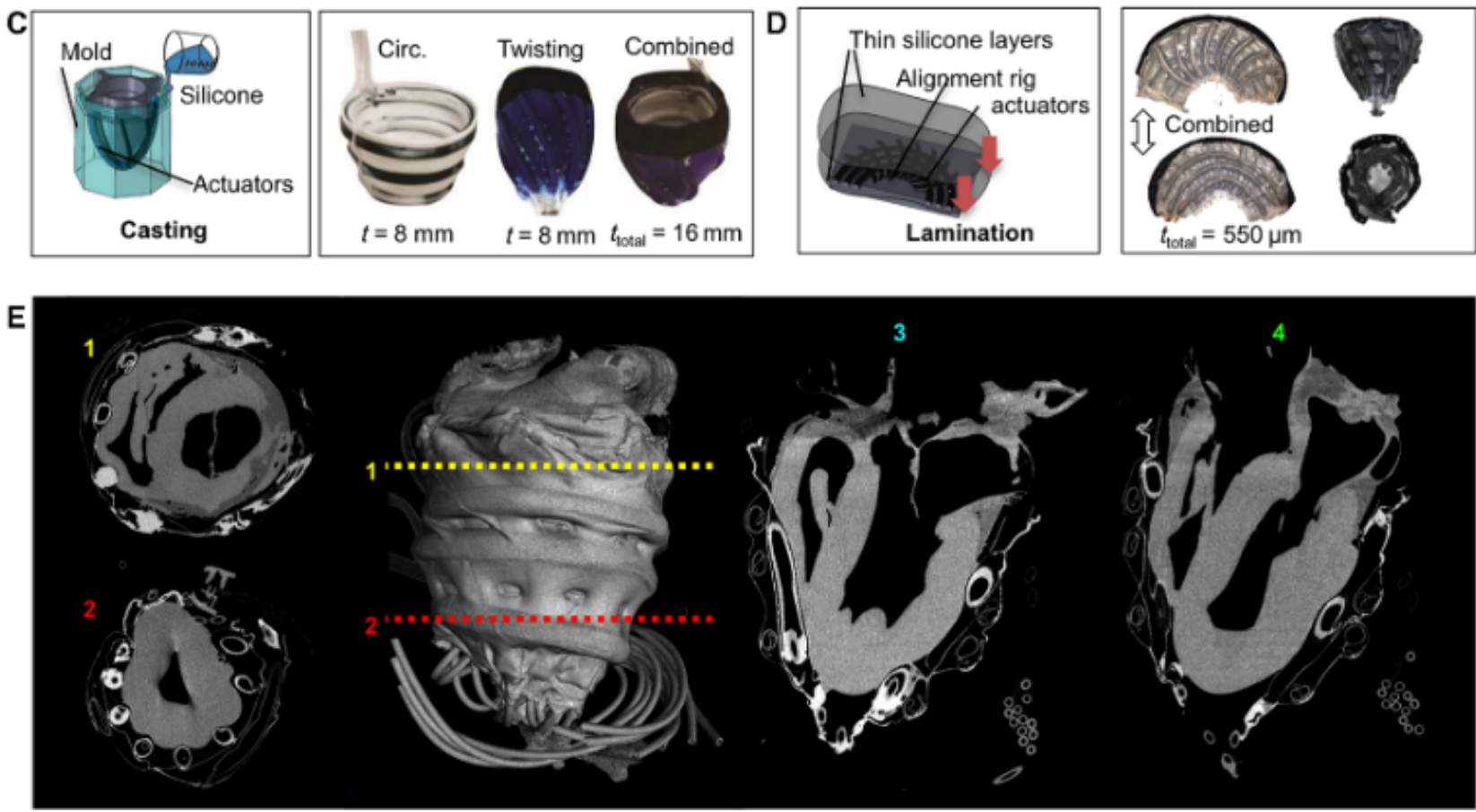

Figure 5: Design and fabrication of a conformal soft robotic sleeve that can compress and twist.

ical properties, thermal properties, and materials selection of the pumps) are the next areas of continuing development. With existing scientific technology, we are still far from an entirely percutaneous, implantable supporting device and long-time implantable assist devices. This will be a reasonable significance of the study to provide less insensitivity, but probably in the next 20 years with the implementation of nanotechnology, such efforts may present simpler and critical assist devices for advanced heart failure. Ongoing research aims the improvement of blood pumps that can be implanted endovascularly, reducing surgical trauma, and then decreasing associated problems like infection and bleeding. Implants materials should be selected to minimize the adverse biologic replication while maintaining the adequate function of the organ. The essential aspects that can investigate by blood pump designers in issues of engineering that are a bloodmaterial interface, unexpected variations in power, sur- face topography, and fluid mechanics to reducing the influence of these factors to thrombus formation and hemolysis. Thrombus formation is a serious issue when designing a long-term implantable heart pump devices. In the purpose of extending survival for long time (7 to 11 years) rather than ( 3 to 5 years) and quality of life, the entirely typical implantable of current pumps; they must include design fundamentals that reduce shear stress and avoid stasis to minimize the events of bleeding, stroke, and pump thrombosis. To overcome problems remain challenging and unresolved such as reducing and preventing the thrombosis formation and obtaining excellent mechanical performance, bioinspired approaches (creating a slippery, liquidinfused, porous surface (SLIPS), introduce the bioinspired liquid-based and a super liquid-repellent gas membrane is designed for anti-thrombosis gating mechanism) are applied to solve these problems in left ventricular assist devices [121]. Design blood pumps in terms of size, must fit 
with any patient weight and create new appropriate materials for reducing hemolysis and platelet aggregation. The biocompatibility property of implantable materials seems too vital aspect to investigate the long-term durability of the devices. The lack of new biocompatible materials creates a gap for scientists worldwide to innovate new materials such as nanotechnology, nanocomposites, and composite materials.

\section{Summary}

The significant aspects that must improve on blood pumps include the miniaturization of the instrument, reducing the effect of thrombosis, and upgrading the valve materials and design. Route of manufacturing the entire artificial organs from nano-technology materials or polymer composites allow to the devices gain more adaptable properties and better efficiency in term of the mechanical properties, biocompatibility, thermal properties and destruction reducing of the pump. The challenges for the designers of heart pumps that should be investigated are low power loss, low hemolysis, inferior thrombus, high reliability and little vibration. Continue developing the pump drive mechanism materials to improve biocompatibility, reduce heat rising from friction and components wear and significantly enhance the performance of the pump. The needs of more and comprehensive studies must be taken into account in the field of material sciences along with the biomechanical sciences. Thus, it provides optimization of design and real concepts for surgical implants. The essential reasons for getting advances development of blood pump performance are the availability of new biocompatible material technology and well-trained teams, in combination with appropriate materials selection. As well as using passive or active surface coatings materials lead to an improvement in the anticoagulation behavior and hemocompatibility. The possible vision of selecting for heart blood pump materials must be constrained by mechanical property considerations and by flexible requirements for material toughness and chemical constancy. The vital factors that may guarantee and leads to keep the products like its original with a human body; this is the device should be biocompatible and patient management of the implant devices.

Acknowledgement: This work was supported by the National Natural Science Foundation of China (Grant number: 81571831) and Shanghai Medical Instrumentation Science Foundation of China (Grant No. 14441900500).

\section{References}

[1] Carr, C. M., J. Jacob, S. J. Park, B. L. Karon, E. E. Williamson, and P. A. Araoz. CT of left ventricular assist devices. Radiographics, Vol. 30, No. 2, 2010, pp. 429-444.

[2] Finocchiaro, T., S. Heinke, M. Leßmann, M. Laumen, U. Steinseifer, T. Schmitz-rode, et al. Design, development, and validation of new VAD/TAH concepts. Biomedizinische Technik. Biomedical Engineering, Vol. 54, 2009, pp. 269-281.

[3] Kafagy, D., and H. Gitano-Briggs. Axial Flow Artificial Heart Blood Pumps: A Brief Review. Trends in Biomaterials \& Artificial Organs, Vol. 27, No. 3, 2013, pp. 124-130.

[4] Williams, D. Advanced applications for materials implanted within the human body. Materials Science and Technology, Vol. 3, No. 10, 1987, pp. 797-806.

[5] Ramakrishna, S., J. Mayer, E. Wintermantel, and K. W. Leong. Biomedical applications of polymer-composite materials: A review. Composites Science and Technology, Vol. 61, No. 9, 2001, pp. 1189-1224.

[6] Askeland, D., P. Fulay, and W. Wright. The science and engineering of materials. Nelson Education, 2011.

[7] Medtronic, www.medtronic.com. Accessibility Statement Apr. 2018.

[8] St Jude Medical, www.sjmprofessional.com. Accessibility Statement 2019.

[9] Teo, A. J., A. Mishra, I. Park, Y.-J. Kim, W.-T. Park, and Y.-J. Yoon. Polymeric biomaterials for medical implants and devices. ACS Biomaterials Science \& Engineering, Vol. 2, No. 4, 2016, pp. 454472.

[10] Harrington, R. One day soon mechanical hearts could replace our flesh and blood ones. 2015. TECH NEWS https://www.business insider.com/mechanical-hearts-could-replace-human-ones-2 015-11?IR=T. Accessed Nov. 10, 2015.

[11] Mac Murray, B. C., X. An, S. S. Robinson, I. M. van Meerbeek, K. W. O'Brien, H. Zhao, et al. Poroelastic foams for simple fabrication of complex soft robots. Advanced Materials, Vol. 27, No. 41, 2015, pp. 6334-6340.

[12] Pacific BioLabs, http://www.pacificbiolabs.com/testing_biocom patibility.asp.

[13] Lam, M. T., and J. C. Wu. Biomaterial applications in cardiovascular tissue repair and regeneration. Expert Review of Cardiovascular Therapy, Vol. 10, No. 8, 2012, pp. 1039-1049.

[14] Potnuru, A., L. Wu, and Y. Tadesse. Artificial heart for humanoid robot. In SPIE Smart Structures and Materials+ Nondestructive Evaluation and Health Monitoring, International Society for Optics and Photonics, 2014, pp. 90562F-90562F, 90516.

[15] Timms, D. A review of clinical ventricular assist devices. Medical Engineering \& Physics, Vol. 33, No. 9, 2011, pp. 1041-1047.

[16] Ishihara, K., N. Shibata, S. Tanaka, Y. Iwasaki, T. Kurosaki, and N. Nakabayashi. Improved blood compatibility of segmented polyurethane by polymeric additives having phospholipid polar group. II. Dispersion state of the polymeric additive and protein adsorption on the surface. Journal of Biomedical Materials Research. Part A, Vol. 32, No. 3, 1996, pp. 401-408.

[17] Lineberry, D. NASA Technology is at the Heart of the Matter. NASA, https://www.nasa.gov/larc/nasa-technology-is-atthe-heart-of-the-matter/. Accessed Feb 27, 2014

[18] Saini, M., Y. Singh, P. Arora, V. Arora, and K. Jain. Implant biomaterials: A comprehensive review. World Journal of Clinical Cases: 
WJCC, Vol. 3, No. 1, 2015, pp. 52-57.

[19] Adabi, M., M. Naghibzadeh, M. Adabi, M. A. Zarrinfard, S. S. Esnaashari, A. M. Seifalian, et al. Biocompatibility and nanostructured materials: Applications in nanomedicine. Artificial Cells, Nanomedicine, and Biotechnology, Vol. 45, No. 4, 2017, pp. 833842.

[20] Carpentier, A., C. Latrémouille, B. Cholley, D. M. Smadja, J.-C. Roussel, E. Boissier, et al. First clinical use of a bioprosthetic total artificial heart: Report of two cases. Lancet, Vol. 386, No. 10003, 2015, pp. 1556-1563.

[21] Cohn, W. E., D. L. Timms, and O. H. Frazier. Total artificial hearts: Past, present, and future. Nature Reviews. Cardiology, Vol. 12, No. 10, 2015, pp. 609-617.

[22] Thunberg, C. A., B. D. Gaitan, F. A. Arabia, D. J. Cole, and A. M. Grigore. Ventricular assist devices today and tomorrow. Journal of Cardiothoracic and Vascular Anesthesia, Vol. 24, No. 4, 2010, pp. 656-680.

[23] Loor, G., and G. Gonzalez-Stawinski. Pulsatile vs. continuous flow in ventricular assist device therapy. Best Practice \& Research. Clinical Anaesthesiology, Vol. 26, No. 2, 2012, pp. 105-115.

[24] Berlin Heart, http://www.berlinheart.de/index.php/mp/content/ products/excor_adult/excor_adult_pumps, in.

[25] Novacor, http://perfusioneducationonline.com/vad/novacor.htm.

[26] Klotz, S., J. Stypmann, H. Welp, C. Schmid, G. Drees, A. Ruksujew, et al. Does continuous flow left ventricular assist device technology have a positive impact on outcome pretransplant and posttransplant? Annals of Thoracic Surgery, Vol. 82, No. 5, 2006, pp. 1774-1778.

[27] Agarwal, S., and K. M. High. Newer-generation ventricular assist devices. Best Practice \& Research. Clinical Anaesthesiology, Vol. 26, No. 2, 2012, pp. 117-130.

[28] Pinney, S. P., A. C. Anyanwu, A. Lala, J. J. Teuteberg, N. Uriel, and M. R. Mehra, Left Ventricular Assist Devices for Lifelong Support, Journal of the American College of Cardiology, Vol. 69, 2017, pp. 2845-2861.

[29] Horie, M., and K. Yamamura. Visualization of main and leakage flow in magnetically suspended centrifugal blood pump. Journal of Visualization / the Visualization Society of Japan, Vol. 15, No. 4, 2012, pp. 353-361.

[30] Wu, H. C., Z. Y. Zhang, P. Chen, and Y. W. Ren, Structure Design and Flow Field Simulation of Magnetic Liquid Suspension Centrifugal Blood Pump, in: Applied Mechanics and Materials, Trans Tech Publ, 2014, pp. 223-227. Available from: https://doi. org/10.4028/www.scientific.net/AMM.624.223.

[31] Pagani, F. D. Continuous-flow rotary left ventricular assist devices with "3rd generation" design. In Seminars in thoracic and cardiovascular surgery, Elsevier, 2008, pp. 255-263.

[32] http://www.mitiheart.com/history-of-development/45566782 45. Accessibility Statement 2012.

[33] Lima, B., M. Mack, and G. V. Gonzalez-Stawinski. Ventricular assist devices: The future is now. Trends in Cardiovascular Medicine, Vol. 25, No. 4, 2015, pp. 360-369.

[34] News Release / HeartWare, http://ir.heartware.com/phoenix.zht $\mathrm{ml} ? \mathrm{c}=187755 \& \mathrm{p}=$ irol-newsArticle \&ID=2068959.

[35] Loforte, A., A. Montalto, F. Ranocchi, P. L. Della Monica, G. Casali, A. Lappa, et al. Levitronix CentriMag third-generation magnetically levitated continuous flow pump as bridge to solution. ASAIO Journal (American Society for Artificial Internal Organs), Vol. 57, No. 4, 2011, pp. 247-253.
[36] Yamazaki, K., S. Kihara, T. Akimoto, O. Tagusari, A. Kawai, M. Umezu, et al. EVAHEART: An implantable centrifugal blood pump for long-term circulatory support. Japanese Journal of Thoracic and Cardiovascular Surgery, Vol. 50, No. 11, 2002, pp. 461-465.

[37] Lim, H. S., N. Howell, and A. Ranasinghe. The physiology of continuous-flow left ventricular assist devices. Journal of Cardiac Failure, Vol. 23, No. 2, 2017, pp. 169-180.

[38] Fan, H.-M, F.-W. Hong, L.-D. Zhou, Y.-S. Chen, Y. Liang, Z.-M. Liu. Design of implantable axial-flow blood pump and numerical studies on its performance. Journal of Hydrodynamics. Ser. B, Vol. 21, 2009, pp. 445-452.

[39] Heilmann, C., U. Geisen, C. Benk, M. Berchtold-Herz, G. Trummer, C. Schlensak, et al. Haemolysis in patients with ventricular assist devices: Major differences between systems. European Journal of Cardio-Thoracic Surgery, Vol. 36, No. 3, 2009, pp. 580-584.

[40] Throckmorton, A. L., and R. A. Kishore. Design of a protective cage for an intravascular axial flow blood pump to mechanically assist the failing Fontan. Artificial Organs, Vol. 33, No. 8, 2009, pp. 611-621.

[41] Wang, W., D. M. Zhu, and W. X. Ding. Development of mechanical circulatory support devices in China. Artificial Organs, Vol. 33, No. 11, 2009, pp. 1009-1014.

[42] Wilson, S. R., M. M. Givertz, G. C. Stewart, and G. H. Mudge, Jr. Ventricular assist devices the challenges of outpatient management. Journal of the American College of Cardiology, Vol. 54, No. 18, 2009, pp. 1647-1659.

[43] Stepanoff, A. J. Centrifugal and Axial Flow Pumps: Theory, Design, and Application. Krieger Publishing Company, 1948.

[44] Yamane, T., T. Ikeda, T. Orita, and T. Tateishi. Fluid dynamics of turbo pumps for artificial hearts. Materials Science and Engineering C, Vol. 4, No. 2, 1996, pp. 99-106.

[45] Korakianitis, T., M. A. Rezaienia, G. M. Paul, A. Rahideh, M. T. Rothman, and S. Mozafari. Optimization of centrifugal pump characteristic dimensions for mechanical circulatory support devices. ASAIO Journal (American Society for Artificial Internal Organs), Vol. 62, No. 5, 2016, pp. 545-551.

[46] Ghanbari, H., H. Viatge, A. G. Kidane, G. Burriesci, M. Tavakoli, and A. M. Seifalian. Polymeric heart valves: New materials, emerging hopes. Trends in Biotechnology, Vol. 27, No. 6, 2009, pp. 359-367.

[47] Jahanmir, S., A. Z. Hunsberger, Z. Ren, H. Heshmat, C. Heshmat, M. J. Tomaszewski, et al. Design of a small centrifugal blood pump with magnetic bearings. Artificial Organs, Vol. 33, No. 9, 2009, pp. 714-726.

[48] Sin, D.-C., H.-L. Kei, and X. Miao. Surface coatings for ventricular assist devices. Expert Review of Medical Devices, Vol. 6, No. 1, 2009, pp. 51-60.

[49] Abu-Omar, Y., and S. S. Tsui. Mechanical circulatory support for AMI and cardiogenic shock. Journal of Cardiac Surgery, Vol. 25, No. 4, 2010, pp. 434-441.

[50] Cotter, C. J., and O.C. Bataille, Heart pump connector. In Google Patents, 2010.

[51] Mielke, N. A., A. L. Massiello, D. J. Horvath, S. M. Benefit, D. Burgess, L. A. Golding, et al. In vitro evaluation of a new resilient, hard-carbon, thin-film coating as a bearing material for ventricular assist devices - In Vitro Bearing Evaluation of BioMedFlex. Journal of Biomedical Science and Engineering, Vol. 3, No. 05, 2010, pp. 525-528.

[52] Garbade, J., H. B. Bittner, M. J. Barten, and F.-W. Mohr. Current trends in implantable left ventricular assist devices. Cardiology 
Research and Practice, Vol. 2011, 2011, id. 290561.

[53] Gregory, S. D., D. Timms, N. Gaddum, D. G. Mason, and J. F. Fraser. Biventricular assist devices: A technical review. Annals of Biomedical Engineering, Vol. 39, No. 9, 2011, pp. 2313-2328.

[54] LaRose, J. A., and C. R. Shambaugh, Stabilizing drive for contactless rotary blood pump impeller. In Google Patents, 2011.

[55] LaRose, J. A., C. R. Shambaugh, D. G. White, L. Rivera, and K. Trichi, Centrifugal rotary blood pump with impeller having a hydrodynamic thrust bearing surface. In Google Patents, 2012.

[56] Liu, G.-M., H.-B. Chen, F.-L. Luo, Y. Zhang, H.-S. Sun, J.-Y. Zhou, et al. Numerical simulation of LVAD inflow cannulas with different tip. International Journal of Chemical Engineering/Sheng Wu Yi Xue Gong Cheng Xue Za Zhi, Vol. 30, No. 1, pp. 141-148.

[57] van Oeveren, W., I. F. Tielliu, and J. de Hart. Comparison of modified chandler, roller pump, and ball valve circulation models for in vitro testing in high blood flow conditions: Application in thrombogenicity testing of different materials for vascular applications. International Journal of Biomaterials, Vol. 2012, 2012, p. 673163.

[58] Zhou, M.-D., C. Yang, Z. Liu, J. P. Cysyk, and S.-Y. Zheng. An implantable Fabry-Pérot pressure sensor fabricated on left ventricular assist device for heart failure. Biomedical Microdevices, Vol. 14, No. 1, 2012, pp. 235-245.

[59] Najjar, S. S., M. S. Slaughter, F. D. Pagani, R. C. Starling, E. C. McGee, P. Eckman, et al. HVAD Bridge to Transplant ADVANCE Trial Investigators. An analysis of pump thrombus events in patients in the HeartWare ADVANCE bridge to transplant and continued access protocol trial. Journal of Heart and Lung Transplantation, Vol. 33, No. 1, 2014, pp. 23-34.

[60] Jamiolkowski, M. A., D. D. Pedersen, W.-T. Wu, J. F. Antaki, and W. R. Wagner. Visualization and analysis of biomaterial-centered thrombus formation within a defined crevice under flow. Biomaterials, Vol. 96, 2016, pp. 72-83.

[61] Selishchev, S. V., and D. V. Telyshev. Optimisation of the SputnikVAD design. International Journal of Artificial Organs, Vol. 39, No. 8, 2016, pp. 407-414.

[62] McGee, E., Jr., K. Chorpenning, M. C. Brown, E. Breznock, J. A. Larose, and D. Tamez. In vivo evaluation of the HeartWare MVAD Pump. Journal of Heart and Lung Transplantation, Vol. 33, No. 4, 2014, pp. 366-371.

[63] Guan, Y., L. Wang, J. Lin, and M. W. King. Compliance study of endovascular stent grafts incorporated with polyester and polyurethane graft materials in both stented and unstented zones. Materials (Basel), Vol. 9, No. 8, 2016, id. 658.

[64] Takami, Y., S. Yamane, K. Makinouchi, Y. Niimi, A. Sueoka, and Y. Nosé. Evaluation of platelet adhesion and activation on materials for an implantable centrifugal blood pump. Artificial Organs, Vol. 22, No. 9, 1998, pp. 753-758.

[65] Mahmood, A. K., W. Kerkhoffs, O. Schumacher, and H. Reul. Investigation of materials for blood-immersed bearings in a microaxial blood pump. Artificial Organs, Vol. 27, No. 2, 2003, pp. 169-173.

[66] Suntornnond, R., J. An, and C. K. Chua. Roles of support materials in 3D bioprinting-Present and future. International Journal of Bioprinting, Vol. 3, No. 1, 2017, pp. 1-4.

[67] Roche, E. T., M. A. Horvath, I. Wamala, A. Alazmani, S.-E. Song, W. Whyte, et al. Soft robotic sleeve supports heart function. Science Translational Medicine, Vol. 9, No. 373, 2017, eaaf3925.

[68] Deutsch, S., J. M. Tarbell, K. B. Manning, G. Rosenberg, and A. A. Fontaine. Experimental fluid mechanics of pulsatile artificial blood pumps. Annual Review of Fluid Mechanics, Vol. 38, No. 1,
2006, pp. 65-86.

[69] Pulsatile Blood Pump. Harvard Apparatus, http://www.harvar dapparatus.com/pulsatile-blood-pumps.html.

[70] Taylor, C. E., Z. W. Dziczkowski, and G. E. Miller. Automation of the harvard apparatus pulsatile blood pump. Journal of Medical Devices, Vol. 6, No. 4, 2012, id. 045002.

[71] Lee, K., C. H. Mun, S. R. Lee, B. G. Min, K. J. Yoo, Y. W. Park, and Y. S. Won. Hemodialysis using a valveless pulsatile blood pump. ASAIO Journal (American Society for Artificial Internal Organs), Vol. 54, No. 2, 2008, pp. 191-196.

[72] Okamoto, E., T. Hashimoto, T. Inoue, and Y. Mitamura. Blood compatible design of a pulsatile blood pump using computational fluid dynamics and computer-aided design and manufacturing technology. Artificial Organs, Vol. 27, No. 1, 2003, pp. 61-67.

[73] Fukunaga, K., A. Homma, A. Funakubo, E. Tatsumi, Y. Taenaka, S. Kitamura, et al. Pulsatile blood pump with a linear drive actuator. Journal of Artificial Organs, Vol. 10, No. 2, 2007, pp. 77-84.

[74] Förster, F., R. Kaufmann, H. Reul, and G. Rau. A small pulsatile blood pump for ventricular support during end-stage heart failure. Artificial Organs, Vol. 24, No. 5, 2000, pp. 373-376.

[75] Abe, Y., T. Chinzei, T. Isoyama, S. Mochizuki, I. Saito, H. Nakagawa, et al. A Small Size Pulsatile Ventricular Assist Device Using An Undulation Pump. ASAIO Journal (American Society for Artificial Internal Organs), Vol. 51, No. 2, 2005, p. 29A.

[76] Iwasaki, K., M. Umezu, K. Iijima, A. Inoue, K. Imachi, and C. X. Ye. Development of a polymer bileaflet valve to realize a low-cost pulsatile blood pump. Artificial Organs, Vol. 27, No. 1, 2003, pp. 78-83.

[77] Gräf, F., T. Finocchiaro, M. Laumen, I. Mager, and U. Steinseifer. Mock circulation loop to investigate hemolysis in a pulsatile total artificial heart. Artificial Organs, Vol. 39, No. 5, 2015, pp. 416-422.

[78] Saisho, R., T. Ohsugi, M. Watada, Y.-J. Kim, K. Ohuchi, S. Takatani, et al. The re-design of transformer portion in transcutaneous energy transmission system for left ventricle assist device. In: World Congress on Medical Physics and Biomedical Engineering 2006, Springer, 2007, pp. 3193-3196. DOI: https://doi.org/10.1007/978-3-540-36841-0_807.

[79] Sayer, G., Y. Naka, and U. P. Jorde. Ventricular assist device therapy. Cardiovascular Therapeutics, Vol. 27, No. 2, 2009, pp. 140150.

[80] Swalen, M.J.P. Study of a bi-directional axial flow blood pump. Brunel University School of Engineering and Design Ph.D. Theses, 2012. Available from: http://bura.brunel.ac.uk/hand le/2438/6343.

[81] Jun, L. Z. R. X. Z., and F. Xin. Experimental study of cavitation phenomenon in a centrifugal blood pump induced by the failure of inlet cannula. Chinese Journal of Mechanical Engineering, Vol. 27, 2014, p. 1.

[82] Hara, S., E. Maeno, X. Li, T. Yurimoto, T. Isoyama, I. Saito, et al. Principle and basic property of the sequential flow pump. Journal of Artificial Organs, Vol. 20, No. 3, 2017, pp. 215-220.

[83] Abe, Y., K. Ishii, T. Isoyama, I. Saito, Y. Inoue, T. Ono, et al. The helical flow pump with a hydrodynamic levitation impeller. Journal of Artificial Organs, Vol. 15, No. 4, 2012, pp. 331-340.

[84] Kyomoto, M., T. Moro, K. Saiga, F. Miyaji, H. Kawaguchi, Y. Takatori, et al. Lubricity and stability of poly(2-methacryloyloxyethyl phosphorylcholine) polymer layer on Co-Cr-Mo surface for hemiarthroplasty to prevent degeneration of articular cartilage. Biomaterials, Vol. 31, No. 4, 2010, pp. 658-668. 
[85] Yamane, T., R. Kosaka, M. Nishida, O. Maruyama, Y. Yamamoto, K. Kuwana, et al. Enhancement of hemocompatibility of the MERA monopivot centrifugal pump: Toward medium-term use. Artificial Organs, Vol. 37, No. 2, 2013, pp. 217-221.

[86] Curtis, A. S., Z. J. Wu, R. L. Kormos, B. P. Griffith, and J. F. Antaki. Novel ventricular apical cannula: In vitro evaluation using transparent, compliant ventricular casts. ASAIO Journal (American Society for Artificial Internal Organs), Vol. 44, No. 5, 1998, pp. M691-M695.

[87] Sun, B. C., K. A. Catanese, T. B. Spanier, M. R. Flannery, M. T. Gardocki, L. S. Marcus, et al. 100 long-term implantable left ventricular assist devices: The Columbia Presbyterian interim experience. Annals of Thoracic Surgery, Vol. 68, No. 2, 1999, pp. 688-694.

[88] Frazier, O. H., R. T. Baldwin, S. G. Eskin, and J. M. Duncan. Immunochemical identification of human endothelial cells on the lining of a ventricular assist device. Texas Heart Institute Journal, Vol. 20, No. 2, 1993, pp. 78-82.

[89] Rose, E. A., H. R. Levin, M. C. Oz, O. H. Frazier, Q. Macmanus, N. A. Burton, and E. A. Lefrak. Artificial circulatory support with textured interior surfaces. A counterintuitive approach to minimizing thromboembolism. Circulation, Vol. 90, No. 5 Pt 2, Nov. 1994, pp. II87-II91.

[90] AFT Fluorotec. The properties and advantages of PTFE, http://www.fluorotec.com/blog/the-properties-and-advantag es-of-polytetrafluoroethylene-ptfe/.

[91] Bélanger, M. C., and Y. Marois. Hemocompatibility, biocompatibility, inflammatory and in vivo studies of primary reference materials low-density polyethylene and polydimethylsiloxane: $\mathrm{A}$ review. Journal of Biomedical Materials Research. Part A, Vol. 58, No. 5, 2001, pp. 467-477.

[92] A. ChemWorx. C. Archives, A. Photonics, Polymer data handbook. Journal of the American Chemical Society, Vol. 131, 2009, pp. 16330-16330.

[93] Yamane, T. Mechanism of artificial heart. Springer, 2016. https://doi.org/10.1007/978-4-431-55831-6.

[94] E.L. Corp., www.edwards.com.

[95] M.M.t.f.a.i.o. materials, p. resource, http://www.matbase.com/ material-categories/natural-and-synthetic-polymers/.

[96] Hoshi, H., T. Shinshi, and S. Takatani. Third-generation blood pumps with mechanical noncontact magnetic bearings. Artificial Organs, Vol. 30, No. 5, 2006, pp. 324-338.

[97] Potapov, E. V., B. Stiller, and R. Hetzer. Ventricular assist devices in children: Current achievements and future perspectives. Pediatric Transplantation, Vol. 11, No. 3, 2007, pp. 241-255.

[98] Griffith, K., E. Jenkins, and F. D. Pagani. First American experience with the Terumo DuraHeart left ventricular assist system. Perfusion, Vol. 24, No. 2, 2009, pp. 83-89.

[99] Nojiri, C. Implantable left ventricular assist system. Circulation Journal, Vol. 73, Supplement A, 2009, pp. A48-A54.

[100] Kihara, S., K. Yamazaki, K. N. Litwak, P. Litwak, M. V. Kameneva, H. Ushiyama, et al. In vivo evaluation of a MPC polymer coated continuous flow left ventricular assist system. Artificial Organs, Vol. 27, No. 2, 2003, pp. 188-192.

[101] Kobayashi, K., K. Ohuchi, H. Hoshi, N. Morimoto, Y. Iwasaki, and S. Takatani. Segmented polyurethane modified by photopolymerization and cross-linking with 2-methacryloyloxyethyl phosphorylcholine polymer for blood-contacting surfaces of ventricular assist devices. Journal of Artificial Organs, Vol. 8, No. 4, 2005, pp. 237-244.
[102] Snyder, T. A., H. Tsukui, S. Kihara, T. Akimoto, K. N. Litwak, M. V. Kameneva, et al. Preclinical biocompatibility assessment of the EVAHEART ventricular assist device: Coating comparison and platelet activation. Journal of Biomedical Materials Research. Part A, Vol. 81, No. 1, 2007, pp. 85-92.

[103] Coleman, D. L., D. Lim, T. Kessler, and J. D. Andrade. Calcification of nontextured implantable blood pumps. ASAIO Journal (American Society for Artificial Internal Organs), Vol. 27, 1981, pp. 97-104.

[104] Schistek, R., A. Genelin, J. Hager, S. Nagl, N. Nessler, F. Stoss, et al. Total implantable axial nonpulsatile blood pump for left ventricular assist and total artificial heart replacement. ASAIO Journal (American Society for Artificial Internal Organs), Vol. 28, 1982, pp. 589-593.

[105] Golding, L. Centrifugal pumps. In Assisted Circulation 2, Springer, 1984, pp. 142-152.

[106] Hauert, R. A review of modified DLC coatings for biological applications. Diamond and Related Materials, Vol. 12, No. 3-7, 2003, pp. 583-589.

[107] Behbahani, M., M. Behr, M. Hormes, U. Steinseifer, D. Arora, O. Coronado, and M. Pasquali. A review of computational fluid dynamics analysis of blood pumps. European Journal of Applied Mathematics, Vol. 20, No. 4, 2009, pp. 363-397.

[108] Heilmann, C., U. Geisen, C. Benk, M. Berchtold-Herz, G. Trummer, C. Schlensak, B. et al. Haemolysis in patients with ventricular assist devices: Major differences between systems. European Journal of Cardio-Thoracic Surgery, Vol. 36, No. 3, 2009, pp. 580584.

[109] Hanson, S. R. Chapter 6 Blood-material Interactions. In: Murphy W., Black J., Hastings G. (Eds) Handbook of Biomaterial Properties. Springer, New York, NY, 2016.

[110] Alavi, S. Towards development of hybrid engineered heart valves. University of California, Irvine, 2014.

[111] Lavery, K. S., C. Rhodes, A. Mcgraw, and M. J. Eppihimer. Antithrombotic technologies for medical devices. Advanced Drug Delivery Reviews, 2016.

[112] Jaganathan, S. K., E. Supriyanto, S. Murugesan, A. Balaji, and M. K. Asokan. Biomaterials in cardiovascular research: Applications and clinical implications. BioMed Research International, Vol. 2014, 2014, id. 459465.

[113] Biological evaluation of medical devices - Part 12: Sample preparation and reference materials," ISO 10993-12:2012.

[114] Kador, K. E., T. G. Mamedov, M. Schneider, and A. Subramanian. Sequential co-immobilization of thrombomodulin and endothelial protein $C$ receptor on polyurethane: Activation of protein C. Acta Biomaterialia, Vol. 7, No. 6, 2011, pp. 2508-2517.

[115] Fedel, M., A. Motta, D. Maniglio, and C. Migliaresi. Surface properties and blood compatibility of commercially available diamond-like carbon coatings for cardiovascular devices. Journal of Biomedical Materials Research. Part B, Applied Biomaterials, Vol. 90, No. 1, 2009, pp. 338-349.

[116] Farooqi, K. M., O. Saeed, A. Zaidi, J. Sanz, J. C. Nielsen, D. T. Hsu, et al. 3D printing to guide ventricular assist device placement in adults with congenital heart disease and heart failure. JACC. Heart Failure, Vol. 4, No. 4, 2016, pp. 301-311.

[117] Berra, I. G., M. L. Berra, M. A. Lewis, H. Vogelfang, G. Naiman, and S. Berra. (998) - Testing 3D Pulsatile Prototypes of Left Ventricular Assist Device. Journal of Heart and Lung Transplantation, Vol. 36, No. 4, 2017, pp. S324-S325. 
[118] Borovjagin, A. V., B. M. Ogle, J. L. Berry, and J. Zhang. From microscale devices to 3D printing. Circulation Research, Vol. 120, No. 1, 2017, pp. 150-165.

[119] Duan, B. State-of-the-art review of 3D bioprinting for cardiovascular tissue engineering. Annals of Biomedical Engineering, Vol. 45, No. 1, 2017, pp. 195-209.

[120] Shahabipour, F., M. Banach, T. P. Johnston, M. Pirro, and A. Sahebkar. Novel approaches toward the generation of bioscaffolds as a potential therapy in cardiovascular tissue engineering. International Journal of Cardiology, Vol. 228, 2017, pp. 319-326.
[121] Sheng, Z.-Z., X. Liu, L.-L. Min, H.-L. Wang, W. Liu, M. Wang, et al. Bioinspired approaches for medical devices. Elsevier, 2017. https://doi.org/10.1016/j.cclet.2017.03.033.

[122] Frazier, O. H., R. D. Dowling, L. A. Gray, Jr., N. A. Shah, T. Pool, and I. Gregoric. The total artificial heart: Where we stand. Cardiology, Vol. 101, No. 1-3, 2004, pp. 117-121.

[123] Rigatelli, G., F. Santini, and G. Faggian. Past and present of cardiocirculatory assist devices: A comprehensive critical review. Journal of Geriatric Cardiology : JGC, Vol. 9, No. 4, 2012, pp. 389400. 